\title{
TOTALLY LAPAROSCOPIC LIVER RESECTION: NEW BRAZILIAN EXPERIENCE
}

\author{
Ressecção hepática totalmente laparoscópica: nova experiência brasileira
}

Croider Franco LACERDA, Paulo Anderson BERTULUCCI, Antônio Talvane Torres de OLIVEIRA

From the Departamento de Cirurgia Oncológica do Aparelho Digestivo Alto, Hospital de Cancer de Barretos (Department of Oncological Surgery of the Upper Gastrointestinal Tract, Barretos Cancer Hospital), Barretos, São Paulo, SP, Brazil.

HEADINGS - Hepatectomy. Laparoscopy. Surgery.
ABSTRACT - Background: Despite the increasing number of laparoscopic hepatectomy, there is little published experience. Aim: To evaluate the results of a series of hepatectomy completely done with laparoscopic approach. Methods: This is a retrospective study of 61 laparoscopic liver resections. Were studied conversion to open technique; mean age; gender, mortality; complications; type of hepatectomy; surgical techniques applied; and simultaneous operations. Results: The conversion to open technique was necessary in one case (1.6\%). The mean age was 54.7 years (17-84), 34 were men. Three patients (4.9\%) had complications. One died postoperatively (mortality 1.6\%) and no deaths occurred intraoperatively. The most frequent type was right hepatectomy (37.7\%), followed by bisegmentectomy (segments II-III and VI-VII). Were not used hemi-Pringle maneuvers or assisted technic. Six patients (8.1\%) underwent simultaneous procedures (hepatectomy and colectomy). Conclusion: Laparoscopic hepatectomy is feasible procedure and can be considered the gold standard for various conditions requiring liver resections for both benign to malignant diseases.

\section{Correspondence:}

Croider Franco Lacerda

E-mail: croider@hotmail.com

Financial source: none

Conflicts of interest: none

Received for publication: 09/01/2014

Accepted for publication: $25 / 03 / 2014$

\section{DESCRTORES - Hepatectomia. \\ Laparoscopia. Cirurgia.}

RESUMO - Racional: Apesar do número crescente de hepatectomias laparoscópicas, ainda há pouca experiência publicada. Objetivo: Avaliar os resultados de uma série de hepatectomia totalmente feita com abordagem laparoscópica. Métodos: Estudo retrospectivo incluindo 61 ressecções laparoscópicas hepáticas. Foram estudadas a conversão para técnica aberta; média de idade; gênero, mortalidade; complicações; tipo da hepatectomia; técnicas cirúrgicas aplicadas; e operações simultâneas. Resultados: A conversão para técnica aberta foi necessária em um caso (1,6\%). A média de idade foi de 54,7 anos (17-84), 34 eram homens. Três pacientes $(4,9 \%)$ tiveram complicações. Um faleceu no pós-operatório (mortalidade de 1,6\%) e não ocorreram óbitos no intra-operatório. O tipo mais frequente foi hepatectomia direita $(37,7 \%)$, seguido por bissegmentectomia (segmentos II-III e VIVII). Não foram utilizados manobras hemi-Pringle ou técnica assistida, e foi evitado o acesso ao pedículo glissoniano (intra-hepática). Seis pacientes $(8,1 \%)$ foram submetidos a procedimentos simultâneos (hepatectomia e colectomia). Conclusão: A hepatectomia laparoscópica é procedimento viável e considerado padrão-ouro para várias condições que necessitam resseções hepáticas tanto para doenças benignas com para malignas.

\section{INTRODUCTION}

$T$ he first laparoscopic liver resection was reported by Reich in $1991^{1,2}$ Subsequently, other reports were published ${ }^{3-5}$. Although the increasing number of laparoscopic hepatectomy, there are still few articles published in the literature and none prospective randomized comparing laparotomic with laparoscopic liver resection. There are 127 published articles, and about 3000 cases of laparoscopic liver resection around the world through $2009^{6}$. The worldwide small number by laparoscopy is due to technical difficulties associated to liver surgery, the high cost of the procedure, and lack of trained teams in liver surgery and advanced laparoscopic surgery. However, this surgery is performed in major centers with experience in laparoscopy with similar good results - even higher - compared to open surgery 7,8 . Currently series published in Japan ${ }^{9}$, Korea ${ }^{10-12}$, China ${ }^{13,14}$, Vietnam ${ }^{15}$, Europe, USA ${ }^{6,16,17}$, United Kingdom ${ }^{18}$, Germany ${ }^{19}$ and Brazil ${ }^{5,20}$, has presented the feasibility of laparoscopic liver resection.

\section{METHOD}

All patients underwent liver resection with access totally by laparoscopy between the years 2009 to 2013, which were analyzed retrospectively from the database collected on medical records. In this period 61 laparoscopic liver resection were performed by the authors on the Department of Oncological Surgery of the Upper Gastrointestinal Tract, Barretos Cancer Hospital, Barretos, São Paulo, SP, Brazil. 


\section{Surgical technique}

The laparoscopic liver resection follows the same anatomical principles, created by Cantlie in 1898 and disseminated by Couinaud in $1957^{21}$. The main hepatic segments resected by laparoscopy were: anatomical and non anatomical segmentectomy, lateral-left hepatectomy, lateral-right hepatectomy, left hepatectomy, right hepatectomy. Also simultaneous resections were involved.

Were used standard laparoscopic instruments. The main arsenal consisted of: laparoscopic forceps mixter 5 and $10 \mathrm{~mm}$; delicate dissector; atraumatic graspers with good grip; good trocar $5 \mathrm{~mm}, 11 \mathrm{~mm}$ and $12 \mathrm{~mm}$. The set of equipment was composed of ultrasonic scalpel (Harmonic $A C E \AA)$ section of the parenchyma and dissection of the hepatic hilum; argon coagulator for hemostasis of parenchyma; laparoscopic ultrasound transducer for identification of parenchyma section line, location of vessel (hepatic vein and the hepatic hilum) and for defining tumor margins.

\begin{tabular}{|c|c|c|}
\hline & Surgical steps & How \\
\hline 1 & $\begin{array}{c}\text { Patient } \\
\text { positioning }\end{array}$ & $\begin{array}{l}\text { The patient is positioned in supine with open } \\
\text { legs and arms (French position). For left or } \\
\text { right hepatectomy, the patient is placed on left } \\
\text { lateral decubitus position }\end{array}$ \\
\hline 2 & Trocars position & $\begin{array}{l}\text { The position and the number of trocars } \\
\text { used depend on the type of resection, with } \\
\text { pneumoperitoneum } 12-15 \mathrm{mmHg}\end{array}$ \\
\hline 3 & $\begin{array}{l}\text { Liver } \\
\text { mobilization }\end{array}$ & $\begin{array}{l}\text { It is performed similar to conventional surgery. } \\
\text { The sectioned falciform ligament, coronary, } \\
\text { triangular and the retro-hepatic vessels when } \\
\text { necessary. The resection of the gallbladder } \\
\text { is accomplished by keeping the gallbladder } \\
\text { attached to the bottom so that it can be used } \\
\text { to expose the hepatic hilum }\end{array}$ \\
\hline 4 & $\begin{array}{l}\text { Hilum } \\
\text { dissection }\end{array}$ & $\begin{array}{l}\text { Identification of the structures of the hilum for } \\
\text { later ligation with laparoscopic linear stapler } \\
\text { (white). In all cases, was used the Echelon } \\
\text { stapler (Johnson \& Johnson) } 45 \mathrm{~mm} \text { or } 60 \mathrm{~mm}\end{array}$ \\
\hline 5 & $\begin{array}{l}\text { Disse } \\
\text { the hep }\end{array}$ & It is dissected and net lin \\
\hline 6 & $\begin{array}{l}\text { Hemostasis and } \\
\text { parenchyma } \\
\text { section }\end{array}$ & $\begin{array}{l}\text { Keep the central venous pressure between } \\
3-5 \mathrm{mmHg} \text {. Use ultrasonic forceps (Harmonic } \\
\text { ACE } ® \text { ), utilized to cut the hepatic parenchyma, } \\
\text { and larger structures are connected with clips } \\
\text { or linear staplers. In minor bleeding, it is used } \\
\text { argon gas for hemostasis }\end{array}$ \\
\hline 7 & $\begin{array}{l}\text { Removal of } \\
\text { the surgical } \\
\text { specimen }\end{array}$ & $\begin{array}{l}\text { The specimen is extracted through suprapubic } \\
\text { incision (Pfannenstiel) or in previous existing } \\
\text { surgical skin scars, with the protection of the } \\
\text { abdominal wall. After removal of the surgical } \\
\text { specimen the anesthetist elevates central } \\
\text { venous pressure, for hemostasis review }\end{array}$ \\
\hline
\end{tabular}

FIGURE 1 - Technical steps for laparoscopic liver resection

\section{Statistical analysis}

The information collected was transferred to a database, and statistical analyzes were performed using SPSS for Windows version (19.0). The descriptive statistics for categorical variables (clinical, pathological, surgical and follow-up) were presented as frequencies and percentages. For continuous variables, mean, standard deviation, minimum and maximum values, were used. The overall survival analysis was based on the product limit estimator of Kaplan-Meier curves; for the comparison between the curves, was used log rank test. The survival time was calculated from the date of liver surgery and the date of last information.
RESULTS

Over a period of five years (2009-2013), 61 liver resections were performed entirely by laparoscopic surgery of which 34 (55.7\%) were males and 27 (44.3\%) females, with a mean age of 54 years (Table 1 ). The most frequent type of liver resection was right liver resection (V-VI-VII and VIII) $23 / 61$ (37.7\%), followed by bisegmentectomy (II-III or VI-VII) $18 / 61$ (29.5\%) (Table 1). The main indication was malignant disease in $88.5 \%$, and due to liver metastases (mainly colorectal carcinoma, 72.1\%). In no case were used hemi-Pringle technique or hybrid technique (hands). Whenever possible the hepatic hilum was accessed by dissection with identification of the structures of the portal triad, thus avoiding pedicle Glissonian intrahepatic approach. Of the 61 patients, the majority (71.2\%) had abdominal surgery performed previously.

In 6/61 cases of liver metastasis from colorectal carcinoma, laparoscopic liver resection was performed simultaneously with colorectal surgery, being two cases with right hepatectomy (V-VI-VII and VIII), two with bisegmentectomy (II-II) and two with left liver resection (IIIII and IVa/b).

TABLE 1 - Number of patients and technical surgical features

\begin{tabular}{l|l|c|c|}
\hline Variables & Categories & $\mathrm{n}$ & $\%$ \\
\hline \multirow{2}{*}{ Gender } & Male & 34 & 55.7 \\
\hline \multirow{2}{*}{ Cases } & Female & 27 & 44.3 \\
\hline \multirow{3}{*}{$\begin{array}{l}\text { Hepatectomy } \\
\text { type }\end{array}$} & Total & 61 & 100.0 \\
\cline { 2 - 4 } & Right (V-VI-VII-VIII) & 23 & 37.7 \\
\cline { 2 - 4 } & Bisegmentectomy (II-III ou VI-VII) & 13 & 21.3 \\
\hline \multirow{3}{*}{ Indication } & Segmentectomy or non anatomical & 7 & 29.5 \\
\hline \multirow{3}{*}{ Pathology } & Malign tumors & 54 & 88.5 \\
\hline & Benign tumors & 7 & 11.5 \\
\hline \multirow{2}{*}{$\begin{array}{l}\text { Associated } \\
\text { techniques }\end{array}$} & Netastasis of colorectal cancer & 44 & 72.1 \\
\hline & Benign tumors & 10 & 16.4 \\
\hline & Assistance of the hand or assisted & 7 & 11.5 \\
\hline & Simultaneous surgery & 0 & 0.0 \\
\hline
\end{tabular}

The body mass index on average was 26.3 , and an obese patient was operated with 39 . The estimated blood loss (85.9 $\mathrm{ml})$, as well as operating time (141.3 min), varied according to the type of resection. Blood transfusions were performed in rare cases, usually submitted to major hepatic resections (Table 2). Diet, in the majority of patients, was started on the first day postoperatively. The average length of stay was 3.6 days, with the majority of hospital discharges on the third day postoperatively, depending on the type of resection, complications and comorbidities (Table 2).

TABLE 2 - Clinical characteristics, surgical and postoperative management

\begin{tabular}{|c|c|c|c|}
\hline Variables & Average & $\begin{array}{c}\text { Standard } \\
\text { deviations }\end{array}$ & $\begin{array}{c}\text { minimum - } \\
\text { maximum }\end{array}$ \\
\hline Age (years) & 54.7 & 15.0 & $17-84.4$ \\
\hline BMI (kg/m2) & 26.3 & 5.3 & $15.2-39$ \\
\hline Surgery time (min.) & 141.3 & 55.4 & $30-310$ \\
\hline $\begin{array}{c}\text { Bleeding (ml) } \\
\text { Initiation of diet (days) }\end{array}$ & 85.9 & 150.6 & $0-1000$ \\
\hline $\begin{array}{c}\text { Discharge from hospital } \\
\text { (days) }\end{array}$ & 3.6 & 0.4 & $1-3$ \\
\hline
\end{tabular}


Regarding complications, there were 3/61 (4.9\%). Of these, one case had intraoperative bleeding during section of the hepatic parenchyma leading to laparotomy conversion, sepsis and death on the sixth day postoperatively - the only death the series (1.6\%). A second case had pelvic abscesses, after simultaneous surgery (left hepatectomy and rectosigmoidectomy) and was treated with percutaneous puncture. The last complication was an internal hernia, also in simultaneous surgery (right hepatectomy and right hemicolectomy). There were no deaths during the intraoperative period. By the time of this publication 36 patients (62.1\%) were alive without disease, $12(20.7 \%)$ with disease and eight (13.8\%) were died due to disease evolution (Table 3).

TABLE 3 - Characteristics related to surgical complications

\begin{tabular}{|c|c|c|}
\hline Variables & $\mathbf{n}$ & $\%$ \\
\hline General complications & 3 & 4.9 \\
\hline Exiguous or compromised margins & 2 & 3.3 \\
\hline Conversion & 1 & 1.6 \\
\hline Intraoperative death & 0 & 0.0 \\
\hline Postoperative mortality & 1 & 1.6 \\
\hline Current status of the disease & $\mathrm{n}$ & $\%$ \\
\hline Alive without disease & 36 & 62.1 \\
\hline Live with disease & 12 & 20.7 \\
\hline Death by disease (cancer) & 8 & 13.8 \\
\hline Death by other causes & 2 & 3.4 \\
\hline
\end{tabular}

Overall survival was estimated dividing the patients into two groups, non-colorectal carcinoma and colorectal carcinoma, based on the date of hepatic resection and the death or last follow-up information. The analysis of the Kaplan-Meier curve had no statistic significant difference between groups, but a tendency to death in the noncolorectal carcinoma group $(p=0.463)$ (Figure 2).

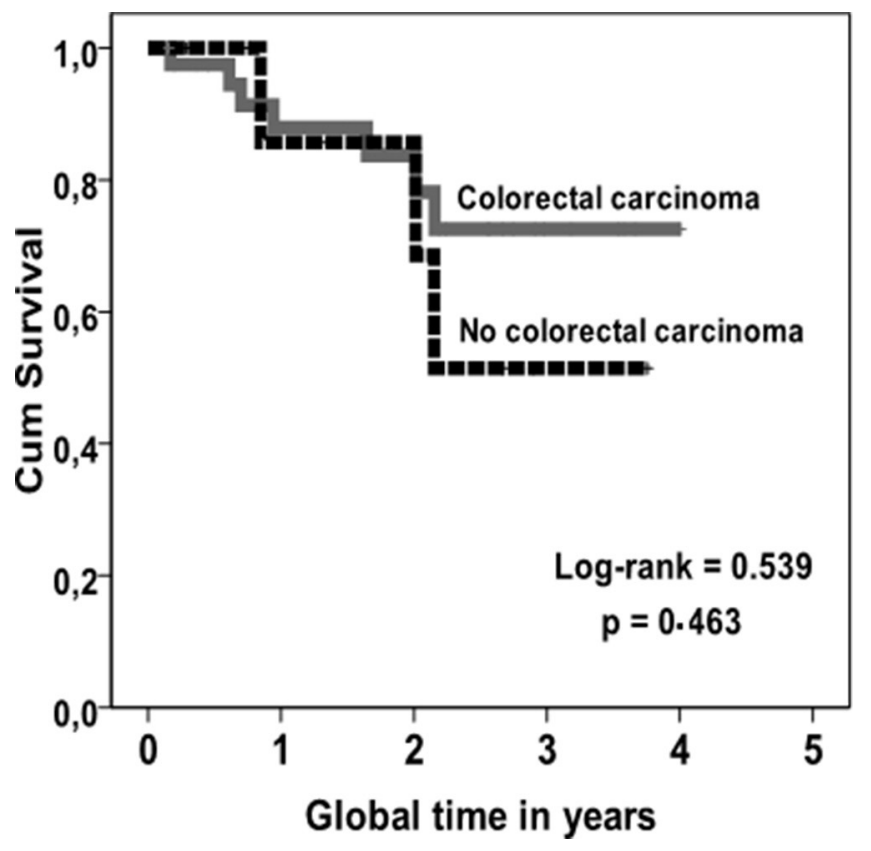

FIGURE 2 - Kaplan-Meier estimated to evaluate the overall survival probability in relation to the date of surgery resection liver metastasis up to the last patient follow-up information

\section{DISCUSSION}

This study is one of the largest series of major liver resections (hemihepatectomy) totally realized by laparoscopic reported by a single team of surgeons.

In the last two decades, laparoscopic procedures revolutionized the surgery. The literature review shows a large increase in the number and indications of laparoscopic liver resection ${ }^{7,22}$. Many procedures previously performed with open surgery (conventional) are now operated by laparoscopic approach with several known advantages compared to laparotomy ${ }^{7}$. At the beginning of laparoscopic liver resection, the indications were for benign diseases. Nowadays, the indications grew mainly due to less blood loss, less postoperative ascites, reduced time of hospital stay and its use in malignant diseases. Dagher et al., in Italy, also demonstrated good results in laparoscopic resections in hepatocellular carcinomas in patients with compensated liver cirrhosis ${ }^{23}$. Cherqui et al. related lower incidence of ascites - the most frequent postoperative complication in cirrhotic patients after liver resection - due to maintenance of collateral circulation in the wall abdominal ${ }^{8}$. In the present series, the procedure was indicated in hepatocellular carcinoma, metastases from different organs and hepatic infiltration in gastric carcinoma.

In 2012, a multicenter Korean study has published 416 cases in 24 hospitals $^{10}$. Another Japanese multicenter study enrolled 2013 cases in 124 hospitals ${ }^{9}$. Tzanis et al., reported European experience, between 1996 and 2011, with a total of 2,245 laparoscopic liver resections, of these 495 (22\%) were for major resections and primary malignant liver tumors, metastatic tumors and benign tumors, $22.4 \%, 19.6 \%$ and $58 \%$, respectively ${ }^{24}$. In this study $88.5 \%$ of indications were for malignant tumors, mostly done with right liver resection (37.7\%) mainly in metastatic colorectal carcinoma. A higher frequency of laparoscopic liver resection for benign diseases or benign liver tumors have been reported in the literature. The large number of liver resections for malignant tumors performed by this surgical team, is justified because patients are treated at a cancer center hospital. In the case of major hepatic resections this study is the largest reported in Brazil $^{5}$ and inversely proportional the larger series published recently ${ }^{6,7,9,10,12,15}$.

The authors experience to access the pedicle or Glissonian intrahepatic technique using laparoscopy is rare in right hepatectomy, reserved when dissection of the hilum or hepatic pedicle is not possible. At left hepatectomy the authors prefer pedicle dissection, that is also supported by other authors $7,16,25,26$, dissecting the hepatic hilum and identifying anatomical variations; for this, the procedure is safer and avoids vascular and bile duct damage $7,16,26$. Moreover, the correct vascular pedicle ligation facilitate section of the parenchyma, not requiring the use of hemi-Pringle maneuver; as this maneuver can cause ischemia in the remaining liver and can lead to liver insufficiency in the postoperative period, especially in those with cirrhosis or treated priorly with chemotherapy (very common in patients with colorectal cancer $)^{27}$. This is possible only with the use of meticulous technique to control blood loss and experience acquired with conventional surgery associating new technologies developed for laparoscopic surgery ${ }^{17}$.

Lupinacci et al., 2013 in a systematic review, reported that despite the lack of evidence, the simultaneous procedure appears to be feasible and safe, even with major liver resection ${ }^{28}$. In the present study, simultaneous operations were done in six patients $(8.1 \%)$ and two had complications in the postoperative period. The best indications for simultaneous surgeries are for patients in whom are proposed resection of segments II-III and VI-VII and right colectomy. The simultaneous resections 
involving extended hepatectomy (right and/or left) and/ or rectosigmoidectomy with low rectal anastomosis should be performed in centers with high expertise in hepatobiliary and colorectal laparoscopic surgery in selected cases. Simultaneous surgical procedures are feasible for patients with good clinical conditions; however, do not have sufficient data and number of cases to define the real benefits for patients.

Despite the great advances in laparoscopic liver surgery with the inclusion of major resections, such as right and left hepatectomy, the resection has remained limited (non anatomical resections, left and right side segmentectomy) ${ }^{29}$. According to Slakey et al., several factors has contributed to the restriction of major hepatic resections in major centers as: hemorrhages with dificulties to maintain vascular control, break of oncological principles (such as inadequate margins), difficulties on liver resection, previous surgeries and high financial $\operatorname{costs}^{29}$. However, several authors has shown a great safety benefits for patients, as less postoperative pain, preservation of the abdominal wall, shorter hospital stay, better cosmetic effect, less bleeding and early return to professional activities ${ }^{22}$. Cherqui et al. reported that laparoscopic liver resection has reduced the bleeding, morbidity and mortality in cirrhotic patients ${ }^{8}$. The good results here presented were not different with the overall reported complication rate. In the present study it was $4.9 \%$; larger series in literature describe $10.5 \%^{6}$, $2.8^{10}, 14.9 \%^{5}$ and $4.5 \%{ }^{9}$.

The estimated blood loss ( $85.9 \mathrm{ml})$, as well as surgery time (141.3 $\mathrm{min}$ ) varied according to the type of resection. Blood transfusions were performed in rare cases, usually submitted to major hepatic resections. Also encouraging results were reported by Rao et al. ${ }^{30}$ : less transfusion, less blood loss, decrease in compromised margins, lower rates of overall complications and lower hospital stay. D i e t was offered, to the vast majority of patients, on the first day after surgery. Similar results were published by Lee et $\mathrm{al}^{22}$. The low operative time and blood loss, probably due to the use of laparoscopic staplers for both pedicle ligation or section of the hepatic parenchyma, also was reported by Buell et $\mathrm{al}^{17}$. The average length of hospital stay was 3.6 days, similar to the majority of hospital discharges, varying according to the type of resection; later hospital discharges are reported in patients with complications and comorbidities. The good evolution of these patients, promotes faster return to home, short hospital stay, less analgesics and, especially, can earlier receive chemotherapy when indicated.

The great advance in hepatic surgery occurred due the development of equipment and instruments for laparoscopic surgery. For this it is essential to have good equipment and $30^{\circ}$ optical device and the use of linear vascular (white) staplers for ligation of the hepatic pedicle and also for the section of the liver parenchyma or ligation of intrahepatic vessels ${ }^{16}$.

\section{CONCLUSION}

Laparoscopic hepatectomy is feasible procedure and can be considered the gold standard for various conditions requiring liver resections for both benign to malignant diseases.

\section{REFERENCES}

1. Abu Hilal M, Di Fabio F, Syed S, Wiltshire R, Dimovska E, Turner D, et al. Assessment of the financial implications for laparoscopic liver surgery: a single-centre UK cost analysis for minor and major hepatectomy. Surg Endosc. 2013 Jul;27(7):2542-50.
2. Buell JF, Gayet B, Han HS, Wakabayashi G, Kim KH, Belli G, et al. Evaluation of stapler hepatectomy during a laparoscopic liver resection. HPB (Oxford). 2013 Jan 18.

3. Cherqui D, Laurent A, Tayar C, Karoui M. [Laparoscopic hepatectomy]. Bull Acad Natl Med. 2007 Nov;191(8):1661-81; discussion 81-2.

4. D'Albuquerque LA, Herman P. [Laparoscopic hepatectomy: is it a reality?]. Arq Gastroenterol. 2006 Jul-Sep;43(3):243-6.

5. Dagher I, O'Rourke N, Geller DA, Cherqui D, Belli G, Gamblin TC, et al. Laparoscopic major hepatectomy: an evolution in standard of care. Ann Surg. 2009 Nov;250(5):856-60.

6. Gagner M. Pioneers in laparoscopic solid organ surgery. Surg Endosc. 2003 Nov;17(11):1853-4; author reply 5.

7. Gumbs AA, Gayet B. Adopting Gayet's Techniques of Totally Laparoscopic Liver Surgery in the United States. Liver Cancer. 2013 Jan;2(1):5-15.

8. Han HS, Yoon YS, Cho JY, Hwang DW. Laparoscopic Liver Resection for Hepatocellular Carcinoma: Korean Experiences. Liver Cancer. 2013 Jan;2(1):25-30.

9. Hwang DW, Han HS, Yoon YS, Cho JY, Kwon Y, Kim JH, et al. Laparoscopic major liver resection in Korea: a multicenter study. J Hepatobiliary Pancreat Sci. 2013 Feb;20(2):125-30.

10.Imura S, Shimada M, Utsunomiya T, Morine $Y$, Wakabayashi $\mathrm{G}$, Kaneko H. Current status of laparoscopic liver surgery in Japan: results of a multicenter Japanese experience. Surg Today. 2013 Jul 26.

11.Kirchberg J, Reissfelder C, Weitz J, Koch M. Laparoscopic surgery of liver tumors. Langenbecks Arch Surg. 2013 Oct;398(7):931-8.

12.Lai EC, Tang CN, Yang GP, Li MK. Minimally invasive surgical treatment of hepatocellular carcinoma: long-term outcome. World J Surg. 2009 Oct;33(10):2150-4.

13.Lee KF, Cheung YS, Chong CN, Tsang YY, Ng WW, Ling E, et al. Laparoscopic versus open hepatectomy for liver tumours: a case control study. Hong Kong Med J. 2007 Dec;13(6):442-8.

14.Liu R. [Laparoscopic hepatectomy: concept and practice]. Zhonghua Wai Ke Za Zhi. 2008 Dec 1;46(23):1766-7.

15.Long TC, Bac NH, Thuan ND, Dat LT, Viet DQ, Chuong LC. Laparoscopic liver resection: 5-year experience at a single center. Surg Endosc. 2013 Nov 7.

16.Lupinacci RM, Andraus W, De Paiva Haddad LB, Carneiro DALA, Herman P. Simultaneous laparoscopic resection of primary colorectal cancer and associated liver metastases: a systematic review. Tech Coloproctol. 2013 Sep 21.

17. Machado MA, Makdissi FF, Surjan RC, Oliveira AC, Pilla VF, Teixeira AR. Intrahepatic Glissonian approach for laparoscopic right trisectionectomy. J Laparoendosc Adv Surg Tech A. 2009 Dec;19(6):777-8; discussion 8-9.

18. Machado MA, Makdissi FF, Surjan RC. Laparoscopic liver resection: personal experience with 107 cases. Rev Col Bras Cir. 2012 Dec;39(6):483-8

19.Nguyen KT, Gamblin TC, Geller DA. World review of laparoscopic liver resection-2,804 patients. Ann Surg. 2009 Nov;250(5):831-41.

20.Pan M, Jiang Z, Cheng Y, Xu X, Zhang Z, Zhou C, et al. Singleincision laparoscopic hepatectomy for benign and malignant hepatopathy: initial experience in 8 Chinese patients. Surg Innov. 2012 Dec;19(4):446-51.

21.Park JS, Han HS, Hwang DW, Yoon YS, Cho JY, Koh YS, et al. Current status of laparoscopic liver resection in Korea. J Korean Med Sci. 2012 Jul;27(7):767-71.

22.Poves I, Martinez-Serrano Mde L, Burdio F, Coll S, Grande L. [Totally laparoscopic right hepatectomy with hilar dissection]. Cir Esp. 2012 Apr;90(4):261-2.

23. Rao A, Rao G, Ahmed I. Laparoscopic vs. open liver resection for malignant liver disease. A systematic review. Surgeon. 2012 Aug;10(4):194-201.

24. Reich H, McGlynn F, DeCaprio J, Budin R. Laparoscopic excision of benign liver lesions. Obstet Gynecol. 1991 Nov;78(5 Pt 2):956-8.

25. Rotellar F, Pardo F, Benito A, Marti-Cruchaga P, Zozaya G, Pedano N. A novel extra-glissonian approach for totally laparoscopic left hepatectomy. Surg Endosc. 2012 Sep;26(9):2617-22.

26.Skandalakis JE, Skandalakis LJ, Skandalakis PN, Mirilas P. Hepatic surgical anatomy. Surg Clin North Am. 2004 Apr;84(2):413-35, viii.

27. Slakey DP, Simms E, Drew B, Yazdi F, Roberts B. Complications of liver resection: laparoscopic versus open procedures. JSLS. 2013 Jan-Mar;17(1):46-55. 
28.Tzanis D, Shivathirthan N, Laurent A, Abu Hilal M, Soubrane $\mathrm{O}$, Kazaryan AM, et al. European experience of laparoscopic major hepatectomy. J Hepatobiliary Pancreat Sci. 2013 Feb;20(2):120-4.

29. Wayand W, Woisetschlager R. [Laparoscopic resection of liver metastasis]. Chirurg. 1993 Mar;64(3):195-7.
30.Zhu Z, Xu Y, Jiao H, Liu R. [Developmental History of laparoscopic liver resection]. Zhonghua Yi Shi Za Zhi. 2011 May;41(3):173-5. 